\title{
A STUDY ON THE SATISFACTION OF STOCK MARKET INVESTORS WITH REFERENCE TO CHENNAI CITY
}

\author{
Dr. S. Mayilvaganan \\ Assistant Professor of Commerce, and A.V.C. College (Autonomous), \\ (Affiliated to Bharathidasan University), Mayiladuthurai, Tamilnadu, India \\ N. Suganthi \\ Research Scholar A.V.C. College (Autonomous), (Affiliated to Bharathidasan University), \\ Mayiladuthurai, Tamilnadu, India
}

\begin{abstract}
Stock market is a place where buying and selling of shares which are already issued. This study is an attempt to find the investment satisfaction of stock market investors. Investor is a person, who expects something such as safety, liquidity, return etc., before investing their money in any one or many investment avenues, but no one can expect or like to take risk. Each and every investor has a wish to earn more return from their investment. Stock market is the only place which gives more return to the investors who are investing in it. The aim the study is to know whether the stock market investors are satisfied or not, because they also expect before investing or after invested in the stock market.
\end{abstract}

Key words: Investment, Liquidity, satisfaction

Cite this Article: S. Mayilvaganan and N. Suganthi, A Study on the Satisfaction of Stock Market Investors with Reference to Chennai City, International Journal of Management, 11(12), 2020, pp 2675-2681.

http://iaeme.com/Home/issue/IJM?Volume=11\&Issue=12

\section{INTRODUCTION}

The recent global economic situation has witnessed immense highs and lows including some unfortunate happenings related to stock market. This has surged a debate on is it really that easy to make money in Indian stock market today. Timing is the most important factor while investing in stock market. The stock market is one of the most interested and inquisitive area for investment. Investment in shares will bring healthier returns compared to any other forms of investment. 


\section{OBJECTIVES OF THE STUDY}

- To know the demographic status of the respondents

- To identify the most attracted investment other than stock market

- To find the savings pattern of the respondents

- To measure the level of satisfaction of the respondents.

\section{STATEMENT OF THE PROBLEM}

Stock market investment is not an easy one because it has many ups and downs. The Indian stock market is not only depending on the Indian Economy, Government policies etc., but it also depends the world economy, so the fluctuation in the stock market is not a newer one. Apart from all many investors not an investors addict of stock market regularly investing in stock market and earning high return within short period and also expediently facing the risk, how they attracted by stock market, in what ways they are satisfying. These two are the basic questions for conducting this study.

\section{RESEARCH METHODOLOGY}

For doing this research both primary and secondary data were collected. Primary data were collected from well structured questionnaire. Secondary data were collected from various books, journals, and websites.

\subsection{Sampling Design}

Convenience sampling was used for this study. The questionnaire was collected from the sample of sample of 80 respondents from T.Nagar in Chennai city.

\subsection{Scaling Technique}

For accessing the level of satisfaction of the investment in stock market, five factors were taken which influence the investors to invest in stock market with help of five point scale they were Highly Satisfied, Satisfied, Neutral, Dissatisfied and Highly Dissatisfied

\subsection{Data Analysis}

After collecting the data it was systematically tabulated and analysed by using SPSS.

\section{LIMITATIONS OF THE STUDY}

- Due to paucity of time this study limited to 80 respondents only.

- The study was conducted in Chennai city so the findings of this study are not applicable for rural and urban investors.

- Owing to time constrains the study doesn't cover the entire Chennai city.

\section{ANALYSIS AND DISCUSSION}

Table - 1

\begin{tabular}{|c|c|c|}
\hline \multicolumn{3}{|c|}{ AGE OF RESPONDENTS } \\
\hline Particulars & Frequency & Percent \\
\hline $20-40$ & 68 & 85 \\
\hline $41-60$ & 10 & 12 \\
\hline Above 60 & 2 & 3 \\
\hline Total & 80 & 100 \\
\hline
\end{tabular}

(Source: primary Data) 
The above table shows the age- wise classification of respondents. It was inferred that the majority of respondents $85 \%$ were belongs to the category of $20-40,12 \%$ were comes under the category of 41- 60 and the remaining $2 \%$ were in the age group of above 60 .

Table - 2

\begin{tabular}{|c|c|c|}
\hline \multicolumn{3}{|c|}{ GENDER OF RESPONDENTS } \\
\hline Particulars & Frequency & Percent \\
\hline Male & 52 & 65 \\
\hline Female & 28 & 35 \\
\hline Total & 80 & 100 \\
\hline
\end{tabular}

(Source: primary Data)

The above table explains the gender of respondents. It was found that $65 \%$ were male, $35 \%$ were female.

Table - 3

\begin{tabular}{|c|c|c|}
\hline \multicolumn{3}{|c|}{ OCCUPATION } \\
\hline Particulars & Frequency & Percent \\
\hline Salaried & 30 & 38 \\
\hline Agriculturist & 22 & 27 \\
\hline Business & 26 & 32 \\
\hline Others & 2 & 3 \\
\hline Total & 80 & 100 \\
\hline
\end{tabular}

(Source: primary Data)

The above table shows the occupation of the investors. It was revealed that $38 \%$ of the investors were salaried people, $27 \%$ were agriculturist, $32 \%$ were doing business and the remaining $2 \%$ were belongs to others such as retired, Housewife.

Table - 4

\begin{tabular}{|c|c|c|}
\hline \multicolumn{3}{|c|}{ MONTHLY INCOME } \\
\hline Particulars & Frequency & Percent \\
\hline Upto 20,000 & 52 & 65.0 \\
\hline $20,0001-40,000$ & 8 & 10.0 \\
\hline $40,001-60,000$ & 16 & 20.0 \\
\hline Above $60,000 \quad$ Total & 4 & 5.0 \\
\hline \multicolumn{1}{|c|}{} & $\mathbf{8 0}$ & $\mathbf{1 0 0 . 0}$ \\
\hline
\end{tabular}

(Source: primary Data)

The above explains the monthly income of the investors. It was found that $65 \%$ were earned up to $20,000,10 \%$ were in the category of $20,001-40,000,20 \%$ were belongs to above 60,000 .

Table - 5

\begin{tabular}{|l|c|c|}
\hline \multicolumn{3}{|c|}{ MARKET EXPERIENCE } \\
\hline \multicolumn{1}{|c|}{ Particulars } & Frequency & Percent \\
\hline Less than 2 years & 38 & 47 \\
\hline 2-3years & 10 & 13 \\
\hline 4 -5 years & 26 & 32 \\
\hline Above 5 years Total & 6 & 7 \\
\hline \multicolumn{2}{|c|}{ T0 } & $\mathbf{1 0 0}$ \\
\hline
\end{tabular}

(Source: primary Data) 
The above table explains the market experience of the stock market investors. It shows that $47 \%$ were less than 2 years. $13 \%$ were experienced $3-4$ years, $32 \%$ were experienced $4-5$ years and the remaining $7 \%$ were experienced above 5 years.

Table - 6

\begin{tabular}{|c|c|c|}
\hline \multicolumn{3}{|c|}{ OTHER INVESTMENT } \\
\hline Particulars & Frequency & Percent \\
\hline Bank Deposits & 38 & 47.5 \\
\hline Insurance & 8 & 10.0 \\
\hline Mutual Fund & 10 & 12.5 \\
\hline Post Office & 6 & 7.5 \\
\hline Gold & 6 & 7.5 \\
\hline Real Estate & 10 & 12.5 \\
\hline Others & 2 & 2.5 \\
\hline Total & 80 & 100 \\
\hline
\end{tabular}

(Source: primary Data)

The above table shows the investment choices of stock market investors other than stock market investment. It shows $47 \%$ were invested in bank deposits, $10 \%$ were invested in insurance, $13 \%$ were invested in mutual fund, $8 \%$ were invested in post office savings, $7 \%$ were invested in gold, $12 \%$ were invested in real estate, $3 \%$ were invested in others such as chit funds, government bonds.

Table - 7

\begin{tabular}{|c|c|c|c|c|c|c|}
\hline \multicolumn{7}{|c|}{ TOTAL SAVINGS * TOTAL INVESTMENT } \\
\hline & & \multicolumn{4}{|c|}{ TOTAL INVESTMENT } & \multirow[b]{2}{*}{ Total } \\
\hline & & $\begin{array}{c}\text { BELOW } \\
5 \%\end{array}$ & $5-10 \%$ & $10-15 \%$ & $\begin{array}{c}\text { ABOVE } \\
15 \%\end{array}$ & \\
\hline \multirow{4}{*}{ 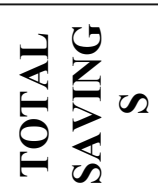 } & Below $10 \%$ & 32 & 2 & 0 & 0 & 34 \\
\hline & $10-20 \%$ & 0 & 26 & 0 & 0 & 26 \\
\hline & $21-30 \%$ & 0 & 0 & 18 & 0 & 18 \\
\hline & Above $30 \%$ & 0 & 0 & 0 & 2 & 2 \\
\hline \multicolumn{2}{|r|}{ Total } & 32 & 28 & 18 & 2 & 80 \\
\hline
\end{tabular}

(source: primary data)

The above gives the information related to savings and investment pattern of investors. It explains percentage of total investment in stock market from their total percentage of savings. It was observed from the table 7, the majority of 32 investors were saving $5 \%$ of from income among the $10 \%$, below $5 \%$ were invested in stock market. 26 investors were $5-10 \%$ from their income among that $10-20 \%$ were invested in stock market.

Table - 8

\begin{tabular}{|l|c|c|}
\hline \multicolumn{3}{|c|}{ DIVIDENDS } \\
\hline \multicolumn{1}{|c|}{ Level of satisfaction } & Frequency & Percent \\
\hline Highly Satisfied & 46 & 57.5 \\
\hline Satisfied & 28 & 35.0 \\
\hline Neutral Total & 6 & 7.5 \\
\hline \multicolumn{2}{c|}{$\mathbf{8 0}$} & $\mathbf{1 0 0}$ \\
\hline
\end{tabular}

Source: primary data 
The table shows the level of satisfaction of investors on the basis getting dividend. It was inferred $57.5 \%$ of the investors were highly satisfied, $35 \%$ of the investors were satisfied. $7.5 \%$ of the investors were felt neutral.

Table - 9

\begin{tabular}{|l|c|c|}
\hline \multicolumn{2}{|c|}{ QUICK GAIN } \\
\hline \multicolumn{1}{|c|}{ Level of satisfaction } & Frequency & Percent \\
\hline Highly Satisfied & 22 & 27.5 \\
\hline Satisfied & 40 & 50.0 \\
\hline Neutral & 14 & 17.5 \\
\hline Dissatisfied & 4 & 5.0 \\
\hline \multicolumn{1}{|c|}{ Total } & $\mathbf{8 0}$ & $\mathbf{1 0 0 . 0}$ \\
\hline
\end{tabular}

Source: primary data

The above table shows the level of satisfaction of investors on the basis of earning quick gain. It shows $27.5 \%$ of the investors were Highly Satisfied, $50 \%$ of the investors were Satisfied, $17 \%$ of the investors were Neutral, $5 \%$ of the investors were Dissatisfied.

Table - 10

\begin{tabular}{|c|c|c|}
\hline \multicolumn{3}{|c|}{ LIQUIDITY } \\
\hline Level of satisfaction & Frequency & Percent \\
\hline Highly Satisfied & 28 & 35 \\
\hline Satisfied & 38 & 48 \\
\hline Neutral & 12 & 15 \\
\hline Dissatisfied & 2 & 2 \\
\hline Total & 80 & 100 \\
\hline
\end{tabular}

Source: primary data

The above table shows the level of satisfaction of investors on the basis of Liquidity of the investment. The majority of the investors $48 \%$ were satisfied, $35 \%$ were highly satisfied, $15 \%$ of the investors were opinioned neutral only $2 \%$ of the investors were dissatisfied.

Table -11

\begin{tabular}{|l|c|c|}
\hline \multicolumn{2}{|c|}{ SAFETY } \\
\hline Level of satisfaction & Frequency & Percent \\
\hline Highly Satisfied & 14 & 18 \\
\hline Satisfied & 38 & 48 \\
\hline Neutral & 26 & 32 \\
\hline Dissatisfied & 2 & 2 \\
\hline \multicolumn{1}{|c|}{ Total } & $\mathbf{8 0}$ & $\mathbf{1 0 0}$ \\
\hline
\end{tabular}

Source: primary data

The above table explains the level of satisfaction of investors on the basis of safety of their investment. $18 \%$ of the investors were highly satisfied on the safety of the investment, $48 \%$ of the investors were Satisfied, $32 \%$ were neutral about the safety of investment and only a little portion of $2 \%$ were dissatisfied. 
Table -12

\begin{tabular}{|l|c|c|}
\hline \multicolumn{3}{|c|}{ TAX BENEFITS } \\
\hline \multicolumn{1}{|c|}{ Level of satisfaction } & Frequency & Percent \\
\hline Highly Satisfied & 16 & 20 \\
\hline Satisfied & 38 & 47 \\
\hline Neutral & 17 & 21 \\
\hline Dissatisfied & 5 & 7 \\
\hline Highly Dissatisfied & 4 & 5 \\
\hline \multicolumn{1}{|c|}{ Total } & $\mathbf{8 0}$ & $\mathbf{1 0 0}$ \\
\hline
\end{tabular}

Source: primary data

The above table revealed the level of satisfaction of investors on the basis of tax benefits. It was found that $20 \%$ of the investors were highly satisfied, $47 \%$ of the investors were satisfied, $21 \%$ of investors were neutral, $7 \%$ of the investors were dissatisfied and the remaining $5 \%$ were highly dissatisfied.

Table -13

Garratt Ranking for Factors Influencing to Invest in Stock Market

\begin{tabular}{|c|c|c|c|c|c|c|c|c|}
\hline Value & \multirow[t]{2}{*}{$1(75)$} & \multirow[t]{2}{*}{$2(60)$} & \multirow[t]{2}{*}{$3(50)$} & \multirow[t]{2}{*}{$4(39)$} & \multirow[t]{2}{*}{$5(24)$} & \multirow{2}{*}{$\begin{array}{l}\text { Total } \\
\text { Score }\end{array}$} & \multirow{2}{*}{$\begin{array}{l}\text { Mean } \\
\text { Score }\end{array}$} & \multirow[t]{2}{*}{ Rank } \\
\hline Particulars & & & & & & & & \\
\hline Dividend & $\begin{array}{c}12 \\
(900)\end{array}$ & $\begin{array}{c}4 \\
(240)\end{array}$ & $\begin{array}{c}24 \\
(1200)\end{array}$ & $\begin{array}{c}16 \\
(624)\end{array}$ & $\begin{array}{c}24 \\
(576)\end{array}$ & 3540 & 44.25 & IV \\
\hline Quick Gain & $\begin{array}{c}16 \\
(1200)\end{array}$ & $\begin{array}{c}36 \\
(2160)\end{array}$ & $\begin{array}{c}12 \\
(600)\end{array}$ & $\begin{array}{c}8 \\
(312)\end{array}$ & $\begin{array}{c}8 \\
(192)\end{array}$ & 4464 & 55.80 & II \\
\hline Liquidity & $\begin{array}{c}40 \\
(3000)\end{array}$ & $\begin{array}{c}12 \\
(720)\end{array}$ & $\begin{array}{c}20 \\
(1000)\end{array}$ & $\begin{array}{c}4 \\
(156)\end{array}$ & $\begin{array}{c}4 \\
(96)\end{array}$ & 4972 & 62.15 & I \\
\hline Safety & $\begin{array}{c}4 \\
(400)\end{array}$ & $\begin{array}{c}20 \\
(1200)\end{array}$ & $\begin{array}{c}20 \\
(1000)\end{array}$ & $\begin{array}{c}32 \\
(1248)\end{array}$ & $\begin{array}{c}4 \\
(96)\end{array}$ & 3844 & 48.05 & III \\
\hline $\begin{array}{l}\text { Tax } \\
\text { Benefits }\end{array}$ & $\begin{array}{c}8 \\
(600)\end{array}$ & $\begin{array}{c}8 \\
(480)\end{array}$ & $\begin{array}{c}4 \\
(200)\end{array}$ & $\begin{array}{c}20 \\
(780)\end{array}$ & $\begin{array}{c}40 \\
(960)\end{array}$ & 3020 & 37.75 & $\mathrm{~V}$ \\
\hline
\end{tabular}

The above tab shows the ranking of various factors which influence the investors to invest in stock market. For this study five factors were taken they are dividend, quick gain, liquidity, safety and tax benefit. Among the five liquidity gets first rank, quick gain gets the second rank, safety gets the third rank, dividend gets the fourth rank and tax benefits gets the last rank.

\section{FINDINGS}

- It was found that the majority of the investors were male and the maximum of investors were comes under the age group of $20-40$.

- It was observed from the study $38 \%$ of the investors were monthly salaried, and they earn the monthly income of below 20,000.

- It was identified that $47.5 \%$ of the investors invest their savings in bank deposits other than stock market.

- It was reveals from the study that $57.5 \%$ of the investors were highly satisfied with their dividend, $50 \%$ were satisfied with quick gain, $48 \%$ were satisfied with their liquidity and safety of investment. $47 \%$ were satisfied with tax benefits.

\section{CONCLUSION}

Stock market is the one of the good investment avenues for earning maximum return, safety of investment, quick gain and also for the liquidity of investment. . Now $-\mathrm{a}-$ days investors have 
positive prospects to invest in stock market. It was concluded from this study the investors of stock market are satisfied their investment in various aspects like safety, liquidity, tax benefits, dividend and quick gain. Finally concluded this study that time period off investment and deep knowledge in market trend give more and more return.

\section{REFERENCES}

[1] Bennet, Ebenezer and Selvam, M., Investors' Perception of the Factors Influencing the Stock Selection Decision (March 24, 2011).

[2] Doran \& Peterson (2006). Analysis of Private Sector Investment in India. Journal of Gyan Management, 2(1), 3-8.

[3] Joshi, M. C., \&Chawla, D. (2015). A Study of Perception of Retail Investors' of Surat City about Factors affecting Primary Market Mechanism in India.

[4] A.Palnitkar, K. Baddade, \& B. Dayma (Ed.), A Paradigm Shift in Indian Business Environment (pp. 49-59).

[5] Keerthi, P. (2009), "Investors' Perception towards Capital Market Investments- With special reference to Coimbatore District", PCTE Journal of Business Management, Vol.2, Issue2, JunDec, pp.41-49.

[6] Vanjeko, R. (2010), "Indian Investors' Investment Characteristics”, Finance India, Vol. XXIV, No.4, Dec, pp.1275-1294. 